\title{
Collection Inventory in a Canadian Academic Dentistry Library ${ }^{1}$
}

\author{
Maria Buda and Helen He
}

\begin{abstract}
Introduction: Collection inventories are time consuming but necessary to clean up catalogue records and improve access and retrieval. This article outlines the methods of carrying out an inventory project at the Dentistry Library, University of Toronto, for the first time in 16 years. As a result, a kit was developed to help implement this project in future years. Description: The kit outlines the steps for the inventory including creating a shelf-list using SIRSIDynix Symphony 3.0's report function, importing into Excel, and separating the collection in smaller sections to make the process less onerous. Outcomes: Readers are informed of the results of this inventory and challenges that arose with the hope that similar projects will be encouraged in other libraries. Collection analysis was not completed in depth, but general conclusions can be stated about the strengths and weaknesses at this time. Discussion: Because of the length of time since the last inventory was completed, this project took longer than expected. The inventory kit, developed from the lessons learned, will facilitate future inventories at the Dentistry Library, as well as other libraries undertaking a collection inventory. Conclusion: Overall, this was a great learning exercise for the Dentistry Library team, and it resulted in improved access to materials by providing users with the correct item information.
\end{abstract}

\section{Introduction}

The Dentistry Library at the University of Toronto is the largest academic dental library in Canada. The library collection began informally in the late 1880 s to support the basic sciences and dentistry curriculum needs of the Royal College of Dental Surgeons (RCDS). In 1888 the RCDS became affiliated with the University of Toronto [1] and the curriculum, as well as the library, broadened in scope and coverage. The library was officially established in 1925 upon the bequest of a library fund in memory of alumnus Dr. Harry Randolph Abbott (1854-1921) [2]. Many inventories were conducted through the history of the library. However, the last inventory prior to this project occurred in 1993 using the kardex.

Staffing and time were barriers that prevented further inventories, but it was decided that the advantages of updating the inventory made the project a priority. Patron frustration at the inconsistencies between the catalogue records and what was on the shelves was the main motivator to start this project. The purpose of the inventory was, therefore, to establish the true holdings of the library. An inventory kit was created at the end of the project cycle to facilitate implementation in future years.

\section{Literature review}

The literature on collection inventories in academic libraries is vast and varied, but for dentistry libraries it is scarce [3]. The collection analysis of the Indiana School of Dentistry Library $[4,5]$ would be an ideal model to follow; however, upon further investigation their having more staff, a larger collection, and better record maintenance, meant that it was not possible to use this model. Darling [6], Stowers [7], and Johnson [8] focused on collection analysis rather than inventory, and although their methods will be useful in future projects, they did not meet our current needs. Cox [4] and Gushrowski [9] focused on weeding the collection, which was also outside of the scope of this project. The two articles of the Joyner Library's Teaching and Resource Centre, East Carolina University, were appropriate for our needs [10, 11]. Similarities included limited human resources, collection size, and the large number of catalogue errors expected.

There was hesitation to start this project, as collection inventories are often thought of as unnecessary and costly. The cost and time needed for this project was unknown, as the number of errors encountered would determine the time spent on correcting them. However, the benefits could not be ignored. Sung's study [12] analysed the cost benefits of conducting an inventory. Braxton's list clearly defined

Maria Buda ${ }^{2}$ and Helen He. Dentistry Library, University of Toronto Libraries, 124 Edward Street, Toronto, ON, M5G 6G1.

${ }^{1}$ This paper has been peer-reviewed.

${ }^{2}$ Corresponding author (e-mail: maria.buda@dentistry.utoronto.ca). 
the importance of keeping accurate records that, in addition to allowing for collection analysis, includes the improvement of OPAC records and confirmation of the items' presence on the shelves [13]. Other positive outcomes of a good inventory include producing a better collection analysis, having accurate data for strategic planning [14], and providing cost effectiveness for things such as insurance purposes [15] and disaster control preparedness [16].

\section{Description}

As Sung [12] noted, there are generally two main steps to inventories: creating a shelf-list and verifying the holdings. A new shelf-list was compiled using the call number reports function in SIRSIDynix Symphony 3.0 (SIRSI), the University of Toronto (UofT) Libraries' integrated library system. This was saved as a commaseparated values (CSV) file and imported into Excel. Unfortunately, this version of the software did not sort by Library of Congress (LC) classification call number. A librarian manually sorted the list in Excel. The small collection allowed for this flexibility, taking a total of about five hours. In addition, many fields were imported from SIRSI as unreadable characters and were manually replaced with the correct item data. For example, sometimes the author field would contain unreadable characters such as "CALL\#\#\#\#". The corrections took about a month to complete, working at a rate of about five hours per week.

For the purpose of this inventory, a very simple SIRSI report was created, including the fields "Year of Publication", "Author", "Title", and "Call Number". The other columns were added manually to Excel (Figure 1). Once the shelf-list was prepared and printed, the part-time staff checked the shelves to see if the items matched the shelflist. The Dentistry Library does not own a scanner that could be taken to the stacks, and it was decided that it was not necessary to borrow one because the literature suggests that inventories are successful whether completed manually [17] or using a scanner [12]. In hindsight, the scanner would probably have made the process faster, as this step took eight months to complete. Part-time staff started in September 2009 and finished in April 2010. Staff were able to devote about four hours per week to the inventory. Missing items were marked on the sheets as such, and items that were not on the list but present on the shelves were flagged for the librarian (Figure 1). A librarian double checked the list a few days after the first check. "Problem items" were investigated before making changes in the SIRSI database. Once the records were corrected, the shelf-list was sub-divided by call number ranges in different Excel tabs and organized by year of publication, with the intention to perform a collection analysis.

\section{Outcomes}

The inventory results are summarized in Table 1 . As of December 2010, there were 11282 catalogue records for print books at the Dentistry Library. The results do not include electronic resources, rare books, theses, audiovisual items, periodicals, or other formats. There were a total of 452 missing items. Four items were catalogued with the old classification system and these were changed to Library of Congress call numbers. There were 85 items whose record existed, but no call number was assigned in SIRSI (although they did have call numbers on the spine). Fifty-one items had a call number in the catalogue that did not match their spine; for example, there were two copies of the same book with each a different call number and there were 19 misshelved books. All call number errors

Table 1. Summary of inventory results.

\begin{tabular}{ll}
\hline Number of items & Type of items \\
\hline 11282 & Catalogue records \\
452 & Missing* \\
4 & On shelf with no catalogue record \\
85 & Catalogued but no call number \\
51 & Call number on record did not match spine \\
19 & Misshelved \\
\hline
\end{tabular}

*These were books that were missing or withdrawn but marked available when automation occurred in 1997.

Fig. 1. Current shelf-list fields.

\begin{tabular}{|c|c|c|c|c|c|c|c|c|c|}
\hline 4 & A & B & c & D & E & $\mathbf{F}$ & G & H & 1 \\
\hline 1 & Year & Author & Title & Call Number & Checked Out & Missing & Stacks & Binding/Repai & Other \\
\hline 143 & NULL & $\begin{array}{l}\text { Canada. } \\
\text { Dominion Bureau } \\
\text { of Statistics. }\end{array}$ & $\begin{array}{l}\text { Canada year book; official statistical annual of the } \\
\text { resources, history, institutions and social and } \\
\text { economic conditions of Canada. }\end{array}$ & HA741.C3 O9 & & & & & \\
\hline 144 & 1971 & Coates, Bryan Ellis & $\begin{array}{l}\text { Regional variations in Britain: studies in economic and } \\
\text { social geography [by] B.E. Coates and E.M. Rawstron. }\end{array}$ & $\mathrm{HC256.6.C6}$ & & & & & \\
\hline 145 & 1981 & $\begin{array}{l}\text { Erskine, James A., } \\
1942 \text {. }\end{array}$ & $\begin{array}{l}\text { Teaching with cases / James A. Erskine, Michiel R. } \\
\text { Leenders, Louse A. Mauffette-Leenders. }\end{array}$ & $\begin{array}{l}\text { HD20.E73 } \\
1981\end{array}$ & & & & & \\
\hline 146 & 1989 & $\begin{array}{l}\text { Task Force on } \\
\text { Access to } \\
\text { Professions and } \\
\text { Trades in Ontario. }\end{array}$ & $\begin{array}{l}\text { Access! / Task Force on Access to Professions and } \\
\text { Trades in Ontario ; Peter A. Cumming, chair ; Enid L.D. } \\
\text { Lee, commissioner, Dimitrios G. Oreopoulos, } \\
\text { commissioner. }\end{array}$ & $\begin{array}{l}\text { HD4903.5.C2 } \\
\text { OS } 1989\end{array}$ & & & & & \\
\hline 147 & 1978 & Spence, Michael. & $\begin{array}{l}\text { Entry, conduct, and regulation in professional markets } \\
\text { : a working paper }\end{array}$ & $\begin{array}{l}\text { HD7038.C2 } \\
\text { OS }\end{array}$ & & $\mathrm{x}$ & & & \\
\hline 148 & 1980 & $\begin{array}{l}\text { Ontario. } \\
\text { Professional } \\
\text { Organizations } \\
\text { Committee }\end{array}$ & $\begin{array}{l}\text { The report of the Professional Organizations } \\
\text { Committee. }\end{array}$ & $\begin{array}{l}\text { HD7038.C2 } \\
\text { O51 }\end{array}$ & & & & & cannot locate \\
\hline 149 & 1932 & $\begin{array}{l}\text { Simons, Algie } \\
\text { Martin, 1870- }\end{array}$ & The way of health insurance & $\begin{array}{l}\text { HD7101.S5 } \\
\text { Dent }\end{array}$ & & & & & \\
\hline
\end{tabular}


were corrected, and items that could not be located were marked missing in SIRSI.

At first, it was alarming that there were 452 books missing. After further investigation, we realized that when automation occurred in 1997 most of the items that were withdrawn or lost were added as available. It is not clear why this happened. Perhaps the records were added to let the public know that at some point these items were part of the collection, and the intention was to mark them missing or withdrawn. Some of the missing books are starting to reappear again, proving that although the list was checked twice, the inventory did not identify all misshelved books.

Patron remarks that the collection is outdated were justified. When organized by year of publication, the number of books decreases with time (Figure 2). It is important to note, however, that this issue is emphasized because we have multiple copies of older books. There are usually just one or two copies of recently published titles; so one might think the collection dated while browsing the stacks.

During the inventory, it was noted that only 27 rare books out of 529 were catalogued. Hence, another outcome of the inventory was a new project to catalogue all rare books and digitize most of them, adding 502 items to our collection [18].

In the summer of 2010, the collection analysis was started with two part-time staff and one librarian assigned to the task. However, owing to the time lapse since the beginning of the project (2009), we decided to stop the project at the inventory level and conduct a more substantial subject analysis at a later time.

Fig. 2. Number of books by publication year from 1980-2010 at the Dentistry Library, University of Toronto Libraries.

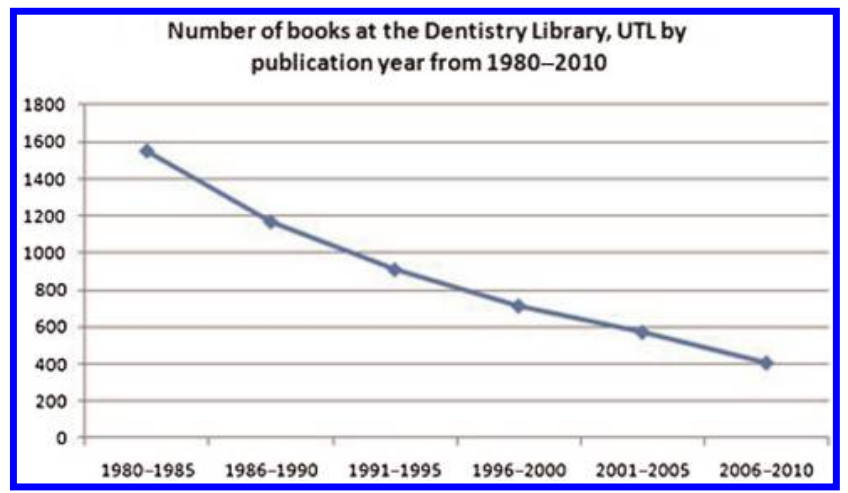

Only broad conclusions about the collection can be made at this time. It was noted that books from small publishers, such as NOVA, were missed. Although the reference collection was relatively up to date, it was lacking items in other languages, professional associations' publications, citation guides, and health science research writing. More in-depth analysis is required to make further conclusions.

\section{Discussion}

The correction of errors in SIRSI will enhance the discoverability of items in our library catalogue by providing accurate item information. Staff are now aware of call number and cataloguing errors to look for in newly acquired resources.

Now that the bulk of the errors were corrected, scanners will be used in future inventories. Although challenges have been reported in the literature [19], it will make the process faster. In addition to print, analysis will include e-books, smaller and independent publishers, and books that are catalogued outside of the Library of Congress classification RK (dentistry) but are relevant to basic sciences for dentistry.

Fig. 3. Dentistry library inventory lit: inventory steps $1-5$.

\begin{tabular}{|c|c|c|}
\hline & LC Call Number Range & Notes \\
\hline Step 1 & A-RK55 & $\begin{array}{l}\text { There are not many } \\
\text { books outside of the } \\
\text { Dentistry Library of } \\
\text { Congress Call Number } \\
\text { RK. However, RK55 is } \\
\text { the first call number } \\
\text { where the number of } \\
\text { books increases. This } \\
\text { range covers Dental } \\
\text { Anaesthesia, Dental } \\
\text { Public Health, Pediatric } \\
\text { Dentistry }\end{array}$ \\
\hline Step 2 & RK56-RK500 & $\begin{array}{l}\text { Dental Anatomy, Oral } \\
\text { Radiology, Oral } \\
\text { Pathology and Medicine, } \\
\text { Endodontics, } \\
\text { Periodontics }\end{array}$ \\
\hline Step 3 & RK501-RK649 & $\begin{array}{l}\text { Orthodontics, Oral and } \\
\text { Maxillofacial Surgery }\end{array}$ \\
\hline Step 4 & RK650-RK669 & $\begin{array}{l}\text { Prosthodontics and } \\
\text { Implantology }\end{array}$ \\
\hline Step 5 & RK700-Z & Pharmacology \\
\hline
\end{tabular}

Fig. 4. Proposed shelf-list fields.

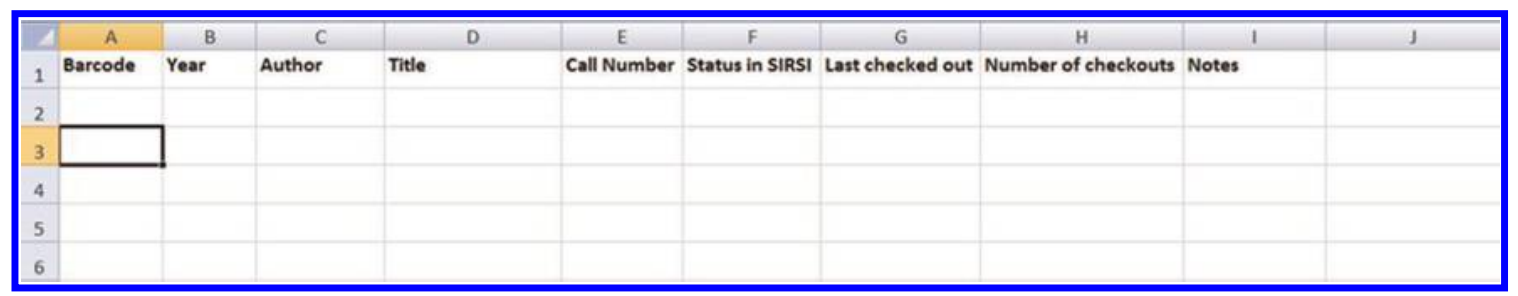


In the planning stage of the project, it was evident that a collection inventory kit was essential to make the process faster and more efficient. Part of this kit includes the instructions for creating a shelf-list in SIRSI (available upon request), and the division of the shelf-list call number ranges into five roughly equal call number ranges (Figure 3). As it took more time than expected to check the shelf-list we plan to do five mini inventories instead of one full one, allowing us to correct the errors found and to start the collection analysis of individual sub-disciplines more quickly. Breaking the project up into steps will also allow for better project control and assessment of progress [20], and it will make the task seem less onerous to staff. Including circulation statistics such as the "last checked out" and the "number of checkouts" fields (Figure 4) will be useful for the collection analysis and possible weeding of the collection.

\section{Conclusion}

The project was a great learning experience for the whole team at the Dentistry Library. Some of the inventory's goals were successfully met, mainly correcting the errors in SIRSI and marking books that were no longer on the shelf as missing. Further analysis is needed to clearly establish the collection strengths and weaknesses with a more systematic method, which we hope to employ in the summer of 2013 when the inventory kit will be put into practice.

\section{Acknowledgements}

This paper is based on a poster presented at the Canadian Health Libraries Association Conference 26-28 May 2011 in Calgary, Alberta, Canada. We would like to acknowledge the conference planning committee. The authors are also indebted to Margot Froud, Reference Technician, for explaining the history of inventories at the Dentistry Library and to all part-time staff that took part in this project, especially David Birtwell, Danielle O'Hearn, and Erica Smith. Thank you to Nalini Singh for helping with the literature review and John Shoesmith for editing.

\section{References}

1. Gullett DW. A history of dentistry in Canada. Toronto: Published for the Canadian Dental Association by University of Toronto Press, 1971.

2. Royal College of Dental Surgeons of Ontario. Report of meetings of the board of directors: special meeting November 23rd, 24th, 1925. Toronto: Royal College of Dental Surgeons of Ontario, 1925.

3. Hook SA, Rossok KM. The Indiana University School of Dentistry Archives: back to the future. Bull Med Libr Assoc. 1998;86(3):416-9.
4. Cox JE, Gushrowski BA. Assessing dental library support for three new campus initiatives using OCLC's WorldCat analysis service. Indiana Libraries. 2008;27(2):54-7.

-5. Cox JE, Gushrowski BA. A dental library book collection intervention: from diagnosis to cure. $J$ Hosp Librariansh. 2008;8(3):352-7. doi:10.1080/15323260802209534.

6. Darling L. Integrating information services for dental schools into a health sciences library. Bull Med Libr Assoc. 1970; 58(2):177-85.

7. Stowers E, Galbraith G. Building a dental sciences collection in a general academic library. Acquisitions Librarian. 2004; 16(31):77-88.

8. Johnson RC, Sims RH. A basic list of recommended books and journals for support of clinical dentistry in a non-dental library. Bull Med Libr Assoc. 1997;85(3):233-8.

9. Gushrowski BA. Moving from good effort to best practice refining a weeding process in a dental school library. Against the Grain. 2007;19(3):26-32.

10. Shouse DL, Teel L. Inventory: catalyst for collection development. Collection Building. 2006;25(4):129-33. doi:10.1108/ 01604950610705998.

11. Teel LM. Applying the basics to improve the collection. Collection Building. 2008;27(3):96-103. doi:10.1108/01604950 810885997.

12. Sung JS, Whisler JA, Sung N. A cost-benefit analysis of a collections inventory project: a statistical analysis of inventory data from a medium-sized academic library. J Acad Librariansh. 2009;35(4):314-23. doi:10.1016/j.acalib.2009.04.002.

13. Braxton B. Inventory: 26 reasons for doing one. Teacher Librarian. 2005;32(4):52-53, 67.

14. Intner SS. Making your collections work for you: collection evaluation myths \& realities. Lib Collect Acquis. 2003; 27(3):339-50.

15. Stedman TJ. Imperatives for regular collection inventories: a New Zealand university library's experience. Lib Collect Acquis. 2010;34(2):51-6.

16. Oehlerts B. Inventory: risk identification and more. Library \& Archival Security. 2009;22(2):73-83. doi:10.1080/01960070902 903995.

17. Henry E, Longstaff R, Van Kampen D. Collection analysis outcomes in an academic library. Collection Building. 2008;27(3):113-7. doi:10.1108/01604950810886022.

18. Internet Archive. The Harry $R$ Abbott Dentistry Library [Internet]. San Francisco: Internet Archive. 2011. Available from: http://www.archive.org/details/utdentistry

19. Ernick L. Floating bibs and orphan bar codes: benefits of an inventory at a small college. Libr Resour Tech Serv. 2005; 49(3):210.

20. Schwalbe K. Information technology project management. 6th ed. Boston (MA): Course Technology/Cengage Learning, 2010 